\title{
INFLUENCE OF DIVERSE CLIMATIC AND SOIL CONDITIONS ON THE PHYSIOLOGICAL AND BIOCHEMICAL ATTRIBUTES AND ANTIOXIDANT ACTIVITIES OF WILD MILK THISTLE (SILYBUM MARIANUM L. GAERT.)
}

\author{
JAVERIA, M. - HUSSAIN, K.* \\ Department of Botany, University of Gujrat, Gujrat, Pakistan \\ *Corresponding author \\ e-mail: khalid.hussain@uog.edu.pk \\ (Received $13^{\text {th }}$ Jan 2020; accepted $6^{\text {th }}$ May 2020)
}

\begin{abstract}
Wild Milk thistle (Silybum marianum L. Gaert.) plants were collected from ten different locations of Punjab, Pakistan during the years 2018 and 2019. These locations have variations for soil characteristics and climatic conditions. Significant variations were noted in all the parameters from location to location as well as year to year. Antioxidant activities i.e. catalases (CAT), peroxidase dismutase (POD) and superoxide dismutase (SOD) changed significantly under fluctuating climatic conditions. Changes in antioxidant activities altered the defense mechanism of milk thistle and caused better balance in plant metabolism to survive. Ionic concentrations (NPK) in stem, leaves and roots also changed significantly. Location Dina showed the best results for physiological, antioxidant activities and ionic contents among all the locations. The soil of Dina location was sandy loam with $0.65 \mathrm{dS} / \mathrm{m} \mathrm{EC}$, $0.65 \%$ organic matter and $47 \%$ soil saturation. Location Dina had a maximum temperature of $25^{\circ} \mathrm{C}$, average temperature of $21{ }^{\circ} \mathrm{C}$ and high amounts of rainfall $(838 \mathrm{~mm}$ ) with $84 \%$ humidity. It was concluded that milk thistle required an optimum soil and climatic conditions similar to location Dina for its best growth and metabolism. These physiological and biochemical indicators can be used to evaluate the milk thistle response towards diverse climatic conditions.
\end{abstract}

Keywords: temperature, plant growth, ion contents, silymarin, rainfall

\section{Introduction}

Silybum marianum (L.) Gaert. generally called as milk thistle that is a yearly/biennial plant belongs to Asteraceae family, Mediterranean territory native and now growing as well as cultivated throughout the world (Bijak, 2017; Abenavoli et al., 2018). Purpose for the cultivation of this plant is to produced silymarin contents (Alemardan et al., 2013), while the other use of this plant is generation of bioenergy as well as oil from seeds and entire plant biomass (Cui et al., 2015; Dominguez et al., 2017). Silymarin complex typically comprises $36.3 \%$ of silybin, $15.7 \%$ silychristin, $5.9 \%$ of silydianin, and $5.1 \%$ of isosilybin that is a liver tonic (Sersen et al., 2006).

Studies related to milk thistle revealed that the growth and crop yield strictly depend upon climatic and environmental conditions and optimum crop cultivation should, therefore, be in accordance with rainfall and temperature regime (Karkanis et al., 2011). The environmental factors effect on seed maturation and agronomic quality of Milk thistle. Accelerated aging of seeds is different between various plant species and inside one seed clone but it induced by several days of exposure to high temperature and high humidity (Wong et al., 1986). Faster aging likewise brought about enhanced peroxidation of lipid, diminished antioxidant levels and also decreased action of a few chemicals associated with peroxides and free radicals scavenging (Bailly et al., 1998; Carlsson et al., 2003). 
Distinctive medicinal species of plant indicated a well-marked variation in dynamic ingredients during various seasons; these have been generally credited to variation in different ecological factors, for example, temperature and rainfall (Ghimire et al., 2006; Kumar et al., 2007; Ahmad et al., 2008, 2009). Impacts of regular changes on biological systems are impinging hugely and progress in climate conditions, temperature variety, patterns of rainfall and corresponding mechanisms are related to natural changes (Root et al., 2003). Analysts opine that synthetic constituent and perseverance of medicinal plants are influenced significantly by climatic changes. Regularly plants under pressure conditions can gather increasingly secondary metabolites because of growth inhibition and fixed carbon diversion in the biosynthesis of phenolics and glycosidic mixes rather than photosynthesis (Gairola et al., 2010).

Contingent on natural variations, photosynthesis vary among species and decline relentlessly with enhancement of leaf age (Herath and Ormrod, 1979). Numerous studies have exhibited that ascent in temperature upgraded the production of secondary metabolites (Litvak et al., 2002), in spite of the fact that others believe that these metabolites declined (Snow et al., 2003). Tholl et al. (2006) also described that increment in temperature just increase the flowing of synthetic production in most plants and the impacts of high temperature are still getting attention (Wahid et al., 2007). Activities of enzymes (CAT, POD and SOD) are a significant index to foretell the plant responses to the changing environments (Sen and Mukherji, 2009). In plants, antioxidants activities may act like a defense line for many troublesome conditions. (Lohrmann et al., 2004). In plants specialized mechanisms for antioxidant defense contains many types of enzymes, for example enlistment of glutathione reductase, POD, CAT, SOD (Keles and Oncel, 2002). Research results show that the yield of milk thistle fruit (Andrzejewska and Sadowska, 2008) is determined by various agro-technological factors, including NPK fertilization.

In the light of above-mentioned literature, the main objectives of this study was to find out the effects of various agro climatic conditions on physio-chemical attributes of milk thistle and to determine the optimum soil and climatic conditions required for its better growth and metabolism.

\section{Materials and methods}

Wild Milk thistle (Silybum marianum L.) plants were collected from ten different locations of Punjab, Pakistan (Jalalpur Jattan, Gujrat, Kharian, Sarai Alamgir, Mandi Bauhudin, Dina, Sohawa, Gujar Khan, Rawalpindi and Islamabad) during the years of 2018 and 2019 as described in Figure Al in the Appendix. Five plant samples were collected randomly from each location between 9:00 am to 2:00 pm. Samples were collected from the away of road side that have no influence of automobile and industries pollutants. The meteorological data of these locations were noted with the help of Pakistan Meteorological Department (PMD), Pakistan. Soil samples were also collected from these locations for the study of soil characteristics with the help of Punjab Agriculture Soil Testing Labs, Pakistan. Photosynthetic pigments like chlorophyll $a, b$ and total chlorophyll and carotenoid contents were measured using the method given by Arnon (1949). Gas exchange parameters such as photosynthetic rate, stomatal conductance, transpiration rate and sub stomatal $\mathrm{CO}_{2}$ concentration were measured from fully expanded young leaves using LCA-4 ADC portable infrared gas analyzer (Analytical Development Company, Hoddeson, England. Model C1-340) along with 
climatic factors described in Table 1. All the measurements were taken between 10:00 am - 02:00 pm as described by Khalid et al. (2017). The adjustments/specifications of IRGA were: leaf surface area $11.35 \mathrm{~cm}^{2}$, temperature of leaf chamber (Tch) varied from 29.2 to $37.5^{\circ} \mathrm{C}$, ambient $\mathrm{CO}_{2}$ concentration (Cref) $349.12 \mu \mathrm{mol} \mathrm{mol}{ }^{-1}$, ambient temperature ranged from $31-36{ }^{\circ} \mathrm{C}$, leaf chamber volume gas flow rate (v) $397 \mathrm{ml} \mathrm{min}^{-1}$, water vapor pressure in chamber ranged from 6-9.0 m bar, molar flow of air per unit leaf area (Us) $401.06 \mathrm{~mol} \mathrm{~m}^{-2} \mathrm{~s}^{-1}$, ambient pressure (P) $99.95 \mathrm{KPa}$, PAR (Q leaf) at leaf surface was up to $1515 \mu \mathrm{molm}^{-2}$.

Table 1. Means of 2018 and 2019 Meteorological data of various locations

\begin{tabular}{c|c|c|c|c|c}
\hline Locations & $\begin{array}{c}\text { Average } \\
\text { rainfall }(\mathbf{m m})\end{array}$ & $\begin{array}{c}\text { Average } \\
\text { temperature }\left({ }^{\circ} \mathbf{C}\right)\end{array}$ & $\begin{array}{c}\text { Minimum average } \\
\text { temperature }\left({ }^{\circ} \mathbf{C}\right)\end{array}$ & $\begin{array}{c}\text { Maximum average } \\
\text { temperature }\left({ }^{\circ} \mathbf{C}\right)\end{array}$ & $\begin{array}{c}\text { Humidity } \\
(\%)\end{array}$ \\
\hline L1(Jalalpur Jattan) & 802 & 20 & 4 & 23.9 & 49 \\
L2(Gujrat) & 706 & 18 & 4 & 19.0 & 76 \\
L3(Kharian) & 809 & 18 & 4 & 23.7 & 78 \\
L4(Sarai Alamgir) & 726 & 18 & 4 & 17.7 & 77 \\
L5(Mandi Bauhudin) & 576 & 10 & 4 & 23.9 & 74 \\
L6(Dina) & 838 & 21 & 4 & 25.5 & 84 \\
L7(Sohawa) & 779 & 13 & 4 & 22.9 & 75 \\
L8(Gujar Khan) & 747 & 18 & 9 & 22.5 & 75 \\
L9(Rawalpindi) & 941 & 15 & 2.5 & 17.0 & 67 \\
L10(Islamabad) & 809 & 17 & 3.6 & 23.0 & 60 \\
\hline
\end{tabular}

Whole plant water use efficiency (WUE) were measured from a mature and intact fully expanded upper leaves by following formula (Guo et al., 2006; Bacon, 2009):

WUE $(\mathrm{g} / \mathrm{L})=($ dry weight of final biomass - dry weight of initial biomass $) /$ total water consumed / rainfall

Estimation of CAT, POD and SOD activities were determined by the procedure of Chance and Maehly (1955). Determination of nitrogen contents according to Kjeldhal procedure as described by Bremner (1965) method and Phosphorous contents was measured with the help of Jackson (1962) method. Contents of potassium were detected with the help of Wolf method (1982).

Data were analyzed statistically using analysis of variance (ANOVA) technique using Ministate-C software. Data were presented as mean \pm SE of five replicates and subjected to one-way analysis of variance (ANOVA) and mean separation was done at $\mathrm{P} \leq 0.05$ by using Tukey's test (Silverman, 2018).

\section{Results}

There were following results from these experiments:

\section{Meteorological characteristics}

Mean data related to meteorology of two years is given in Table 1. Data was collected for those months (October, November, December, January, February, March and April) in which milk thistle completed its life cycle. Data was complied with the help Pakistan Meteorological Department (PMD) from ten different locations which 
were under considerations. All the locations had varied rainfall, average, minimum and maximum temperature and humidity. Maximum rainfall $(838 \mathrm{~mm})$ was noted in location Dina and minimum $(576 \mathrm{~mm})$ rainfall was noted in Mandi Bauhudin. Maximum average temperature $\left(21^{\circ} \mathrm{C}\right)$ was in location Dina and minimum in location Sohawa $\left(13^{\circ} \mathrm{C}\right)$. In Location Dina maximum temperature was noted upto $25.5^{\circ} \mathrm{C}$. Location Dina had also maximum humidity $(84 \%)$.

\section{Soil properties}

Physiochemical soil properties were studies of all the locations from which wild plants of milk thistle were collected (Table 2). There were clay loamy soils in all the locations except Rawalpindi and Islamabad. Soil collected from location Dina was best due low EC, normal $\mathrm{pH}$, high organic matter, nitrogen and potassium contents. There was high soil saturation \% in location Dina that was 46 while other locations had upto $40 \%$ soil saturation percentage.

Table 2. Physiochemical properties of the soil collected from various locations

\begin{tabular}{c|c|c|c|c|c|c|c|c}
\hline Soil characteristics & Soil texture & $\begin{array}{c}\mathbf{E C} \\
(\mathbf{d S} / \mathbf{m})\end{array}$ & $\mathbf{p H}$ & $\begin{array}{c}\text { Organic } \\
\text { matter }(\mathbf{\%})\end{array}$ & $\mathbf{N}(\mathbf{m g} / \mathbf{k g})$ & $\mathbf{P}(\mathbf{m g} / \mathbf{k g})$ & K (mg/kg) & $\begin{array}{c}\text { Saturation } \\
\mathbf{\%} \mathbf{a g e}\end{array}$ \\
\hline L1(Jalalpur Jattan) & Clay loam & 0.98 & 7.1 & 0.45 & 0.44 & 3 & 112 & 40 \\
L2(Gujrat) & Clay loam & 0.88 & 7.6 & 0.77 & 0.88 & 5 & 102 & 40 \\
L3(Kharian) & Clay loam & 0.88 & 7.3 & 0.69 & 0.31 & 5 & 104 & 40 \\
L4(Saraialamgeer) & Clay loam & 0.75 & 7.5 & 0.66 & 0.22 & 5 & 98 & 40 \\
L5(Mandi Bauhudin) & Clay loam & 0.74 & 7.0 & 0.57 & 0.16 & 5 & 98 & 38 \\
L6(Dina) & Clay loam & 0.65 & 7.2 & 0.85 & 0.87 & 5 & 100 & 46 \\
L7(Sohawa) & Clay loam & 0.75 & 7.1 & 0.62 & 0.12 & 7 & 98 & 42 \\
L8(Gujarkhan) & Clay loam & 0.85 & 7.2 & 0.50 & 0.32 & 3 & 102 & 40 \\
L9(Rawalpindi) & Sandy clay loam & 1.07 & 7.6 & 0.55 & 0.74 & 6 & 98 & 42 \\
L10(Islamabad) & Sandy clay loam & 1.02 & 7.5 & 0.57 & 0.76 & 3 & 114 & 40 \\
\hline
\end{tabular}

\section{Photosynthetic pigments}

Results from analysis of variance (ANOVA) indicated that the effect of different climatic conditions on chlorophyll $\mathrm{a}, \mathrm{b}$, total chlorophyll and carotenoids contents were highly significant among different locations, years and their interaction in milk thistle collected from various locations (Table 3). Figure 1A-D showed that maximum amount of chlorophyll a, b total and carotenoids contents were recorded at L6 (Dina) in 2019 and minimum contents at L8 (Gujar Khan) in 2018. Location Dina was also best for soil and climatic conditions. Overall, there were high contents of photosynthetic pigments in the plants collected 2019 as compared to 2018.

\section{Photosynthetic rate}

Data revealed that maximum rate of photosynthesis was measured in the plants collected from L6 (Dina) during 2019 (Fig. 1E). ANOVA related to of photosynthetic rate was highly significant for locations, years and its interaction (Table 3). Photosynthetic rate was significantly varied under different locations by the influence of ecological conditions. There was low photosynthetic rate during the year 2018 that might be due to changes in climatic conditions observed in both the years. 


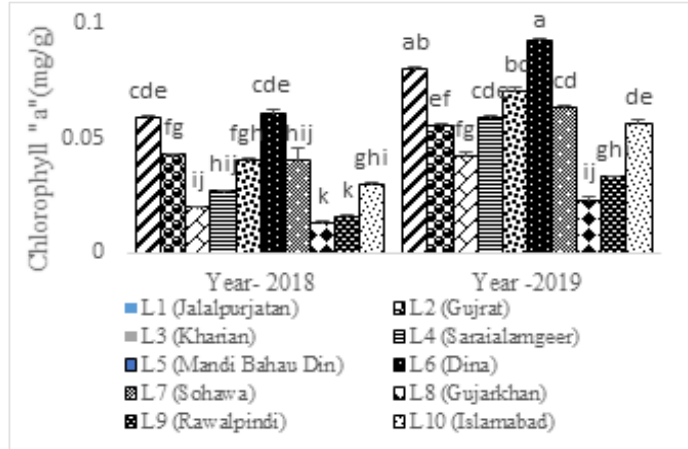

(A) Chlorophyll "a" (mg/g)

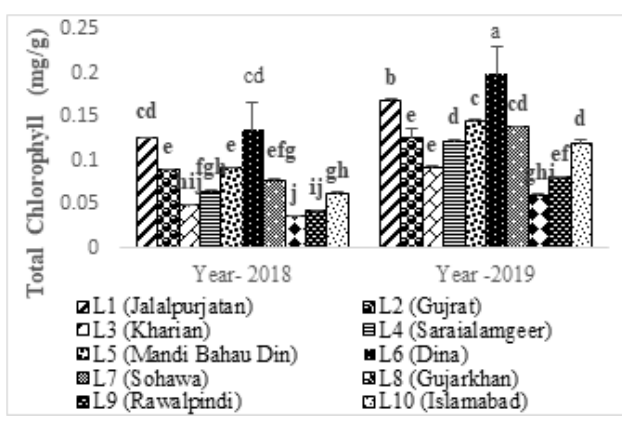

(C) Total chlorophyll (mg/g)

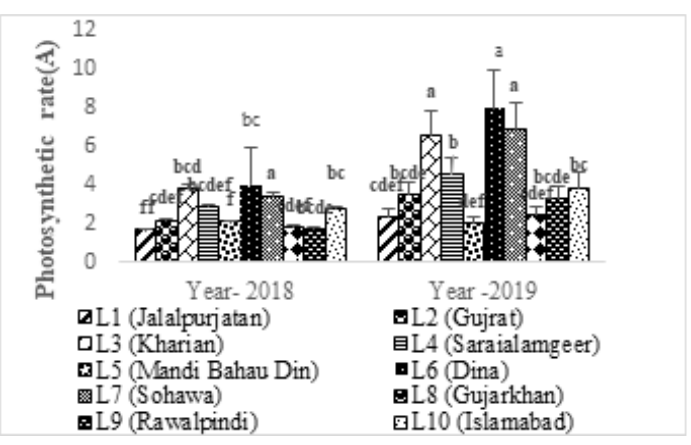

(E) Photosynthetic rate (A)

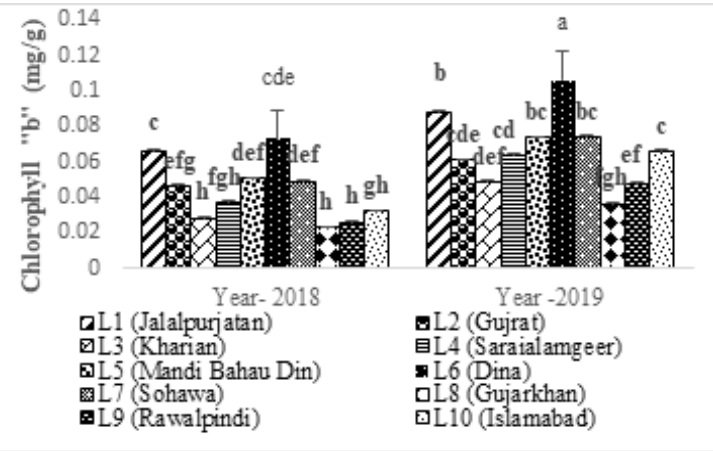

(B) Chlorophyll "b" (mg/g)

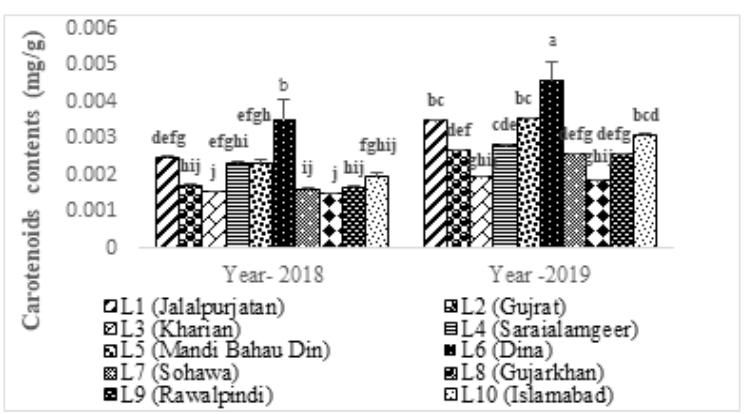

(D) Carotenoids contents $(\mathrm{mg} / \mathrm{g})$

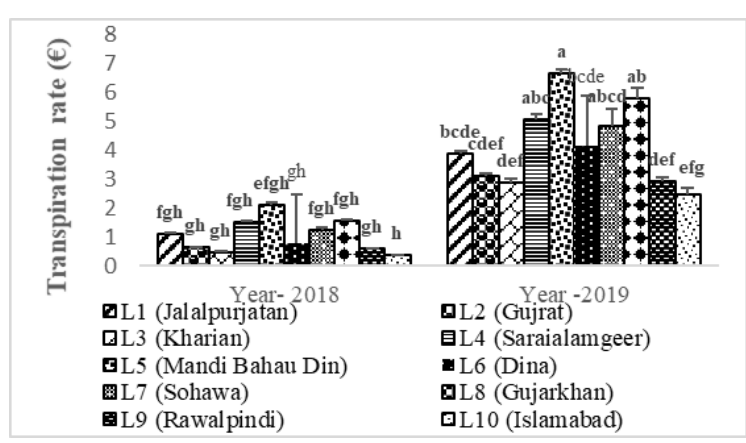

(F) Transpiration rate $(€)$

Figure 1. Influence of climatic conditions on photosynthetic and physiological attributes of milk thistle (Silybum marianum) at various ecological locations

\section{Transpiration rate}

Table 3 demonstrated that the impact of environmental factors on transpiration rate of milk thistle was highly significant among all the location. Variations among years and its interaction were also highly significant. High transpiration rate of milk thistle was noted in 2019 as compared to 2018 (Fig. 1E). Highest transpiration rate was noted in 2019 at Location-5 (Mandi Bahaudin) and minimum at Location-10 (Islamabad) in 2018. Results also indicated that effect of factors on transpiration rate was highly observed at Location-5 (Mandi Bahaudin) during 2018 as well as in 2019. High temperature resulted high rate of transpiration in milk thistle.

\section{Stomatal conductance}

Effect of various ecological factors (temperature, soil and rain fall) had significant results stomatal conductance. Variations between years were significant while, 
interaction between locations and years was non-significant results (Table 3). Maximum stomatal conductance was observed in 2018 and minimum in 2019 (Fig. 2A). Data narrated that high stomatal conductance was noted at L8 (Gujar Khan) in 2018 and low conductance was in 2019 at L2 (Gujrat). During 2018, there was less variations in the data related to stomatal conductance. These changes were due to variations in climatic conditions in the both the years.

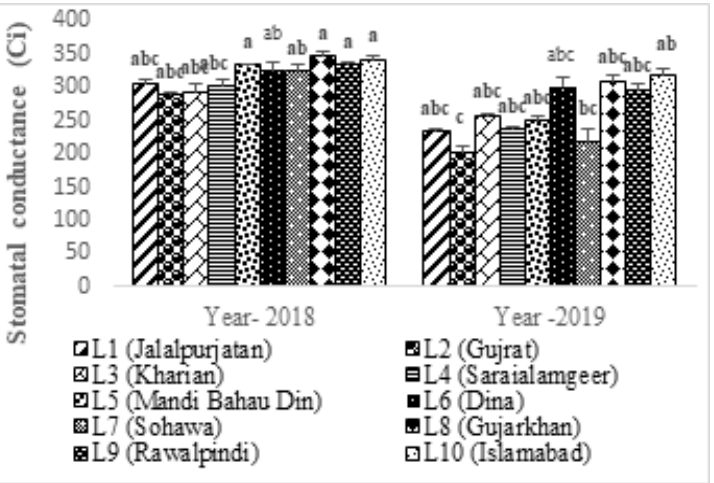

(A) Stomatal conductance $(\mathrm{Ci})$

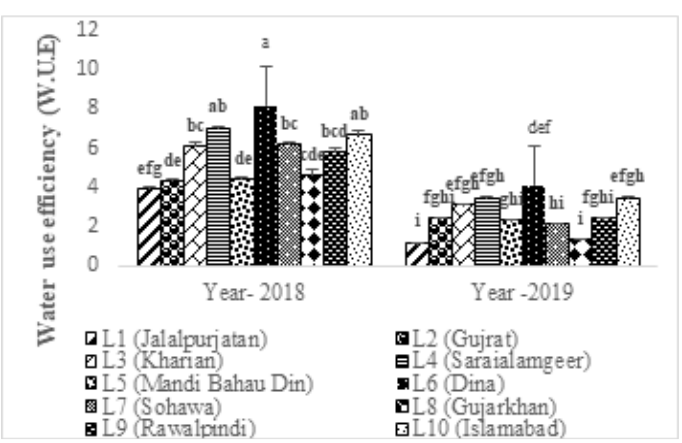

(C) Water use efficiency (W.U.E)

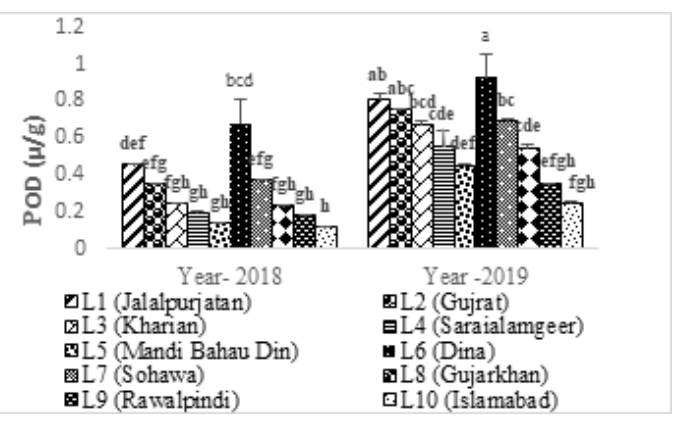

(E) POD $(\mu / g)$

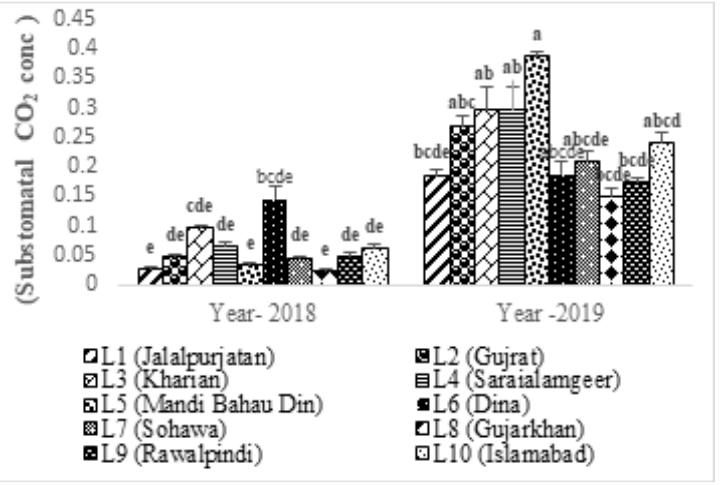

(B) Substomatal CO2 conc

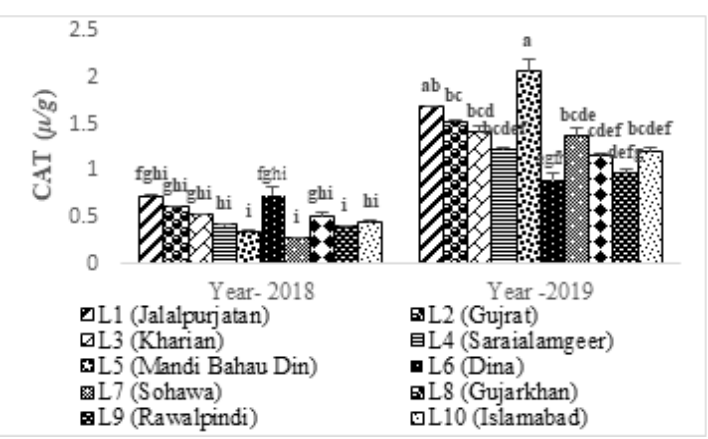

$\operatorname{CAT}(\mu / g)$

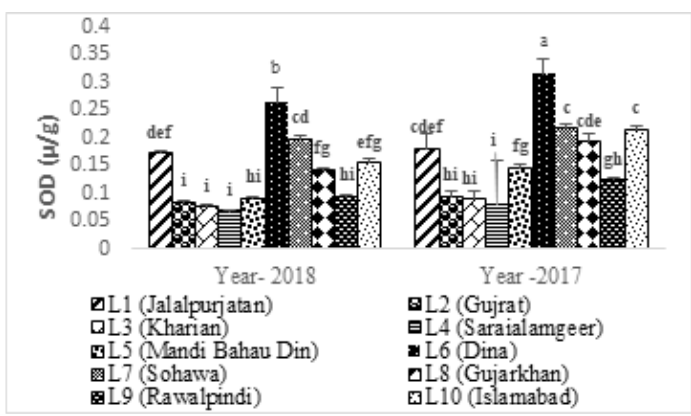

(F) $\operatorname{SOD}(\mu / g)$

Figure 2. Influence of climatic conditions on physiological attributes and antioxidant activities of milk thistle (Silybum marianum) at various ecological locations

\section{Substomatal $\mathrm{CO}_{2}$ concentrations}

Results present in Table 3 indicated that effect of different environmental conditions was significant on concentration of substomatal $\mathrm{CO}_{2}$. Response of years and its interaction with locations was also highly significant. Concentration of substomatal $\mathrm{CO}_{2}$ 
was high during 2019 as compared to 2018 (Fig. 2B). Figure 2B illustrated that high concentration of substomatal $\mathrm{CO}_{2}$ was detected in 2019 at L5 (Mandi Bahaudin) and low values were noted in 2018 at L8 (Gujar Khan).

\section{Water use efficiency (WUE)}

Effect of climatic conditions was highly significant on whole water use efficiency of milk thistle (Table 3). High water use efficiency was noted at L6 (Dina) in 2018 and low water use efficiency was noted in 2019 at L1 (Jalalpur Jattan) due to climatic temperature and rainfall variations among locations and years (Fig. 2C). Water use efficiency was high during 2018 as compared to 2019. Location-6 (Dina) showed highest values on water use efficiency in both years as it has much varied climatic conditions from other location.

\section{Catalase activity $($ CAT)}

Effect of ecological factors on CAT was highly significant. Year response was also highly significant with its interaction (Table 4). Results from Figure $2 D$ narrated that best antioxidant activities of CAT were noted at L5 (Mandi Bahaudin) in 2019 and low activity was in 2018 at L7 (Sohawa). Results also indicated that highest Catalase activities were observed in 2019 at all locations. CAT activities can be good indicators to show the environmental variation.

\section{Peroxidase activity (POD)}

Table 4 demonstrated that impact of various ecological factors was highly significant for POD activities with yearly and their interaction. Figure $2 E$ indicated that high POD activities were obtained at Location-6 (Dina) in 2019 and minimum in 2018 at L10 (Islamabad). POD activities were high during at Dina during both the years 2018 and 2019. It was also clear from the results that in 2019 highest POD activities were obtained in comparison with 2018.

\section{Superoxide-dismutase activity (SOD)}

ANOVA results showed that SOD actvities were highly significant in milk thistle under varied cliamtic conditions (Table 4). Figure $2 F$ indicated that maximum activities of SOD were observed at L6 (Dina) in 2019 and Minimum activities was detected at L4 (Sarai Alamgir) in 2018. Results also revealed that the effect of factors on superoxidedismutase activities was highly detected in all location of 2019 as compare to 2018. Changes in SOD was due to variations in climatic conditions.

\section{Nitrogen $(N)$ contents $(\mathrm{mg} / \mathrm{g})$}

Means square from ANOVA (Table 5) showed effect of ecological factors on nitrogen contents in root, stem, leaves and seeds were highly significant. Results indicated that effect of temperature, rain fall, soil and $\mathrm{pH}$ on nitrogen contents was highly significant among different variation and years. While the interaction between location and years showed non-significant results. Figure $3 A$ showed that maximum contents of nitrogen were noted in stem part and minimum contents of nitrogen was noted in seeds at both 2018 and 2019. However, L6 (Dina) showed highest contents of nitrogen on all plants part at both the years. 
Table 3. Means squares (MS) from the Analysis of variance (ANOVA) for photosynthetic and physiological attributes of milk thistle (Silybum marianum) collected from various ecological locations

\begin{tabular}{|c|c|c|c|c|c|c|c|c|c|c|}
\hline Source & df & MS of chlorophyll a & MS of chlorophyll b & $\begin{array}{l}\text { MS of total } \\
\text { chlorophyll }\end{array}$ & $\begin{array}{l}\text { MS of total } \\
\text { carotenoids }\end{array}$ & $\begin{array}{c}\text { MS of } \\
\text { photosynthetic } \\
\text { rate }\end{array}$ & $\begin{array}{c}\text { MS of } \\
\text { transpiration } \\
\text { rate }\end{array}$ & $\begin{array}{c}\text { MS of } \\
\text { stomatal } \\
\text { conductance }\end{array}$ & $\begin{array}{c}\text { MS of substomatal } \\
\mathrm{CO}_{2} \text { conc. }\end{array}$ & $\begin{array}{c}\text { MS of water use } \\
\text { efficiency } \\
\text { (W.U.E) }\end{array}$ \\
\hline Location & 9 & $0.03422 * * *$ & $0.003419^{* * *}$ & $0.013743^{* * *}$ & $0.000005^{* * *}$ & $29.4768^{* * *}$ & $9.599 * * *$ & $8406^{* * *}$ & $0.016912 * *$ & $12.535^{* * *}$ \\
\hline Year & 1 & $0.013512^{* * * *}$ & $0.013366^{* * *}$ & $0.048146^{* * *}$ & $0.000018^{* * *}$ & $30.008 * * *$ & $248.252 * * *$ & $81693 * * *$ & $0.808201 * * *$ & $244.844 * * *$ \\
\hline Location $\times$ year & 9 & $0.000238 * * *$ & $0.000107 * *$ & $0.001104 * * *$ & $0.000001^{*}$ & $4.5499 * * *$ & $1.810^{* *}$ & $2155 \mathrm{~ns}$ & $0.016710 * *$ & $1.326^{* * *}$ \\
\hline Error & 80 & 0.000033 & 0.000042 & 0.000065 & 0.000002 & 0.6175 & 0.803 & 2375 & 0.007338 & 0.552 \\
\hline Total & 99 & 0.049095 & 0.048460 & 0.187002 & 0.000073 & 385.65 & 415.20 & 366761 & 1.6979 & 413.73 \\
\hline
\end{tabular}

Table 4. Means squares (MS) from the analysis of variance (ANOVA) for antioxidant activities of milk thistle (Silybum marianum) collected from various ecological locations

\begin{tabular}{c|c|c|c|c}
\hline Source & df & MS of catalase activity (CAT) & MS of peroxidase activity (POD) & MS of superoxide-dismutase activity (SOD) \\
\hline Location & 9 & $0.3210^{* * *}$ & $0.35089^{* * *}$ & $2.33356^{* * *}$ \\
Year & 1 & $18.0889^{* * *}$ & $0.02295^{* *}$ & $0.046313^{* * *}$ \\
Location $\times$ year & 9 & $0.4030^{* * *}$ & 0.01031 & $0.023525^{* * *}$ \\
Error & 80 & 0.0468 & $0.001117^{* * *}$ \\
Total & 99 & 28.345 & 0.000272 \\
\hline
\end{tabular}

Table 5. Means squares (MS) from the analysis of variance (ANOVA) for ion concentrations in milk thistle (Silybum marianum) collected from various ecological locations

\begin{tabular}{|c|c|c|c|c|c|c|c|c|c|c|c|c|c|}
\hline Source & df & $\begin{array}{l}\text { MS of N- } \\
\text { contents in } \\
\text { root }\end{array}$ & $\begin{array}{l}\text { MS of N- } \\
\text { contents in } \\
\text { stem }\end{array}$ & $\begin{array}{l}\text { MS of N- } \\
\text { contents in } \\
\text { leaves }\end{array}$ & $\begin{array}{l}\text { MS of N- } \\
\text { contents in } \\
\text { seeds }\end{array}$ & $\begin{array}{l}\text { MS of K- } \\
\text { contents in } \\
\text { root }\end{array}$ & $\begin{array}{l}\text { MS of K- } \\
\text { contents in } \\
\text { stem }\end{array}$ & $\begin{array}{l}\text { MS of K- } \\
\text { contents in } \\
\text { leaves }\end{array}$ & $\begin{array}{l}\text { MS of K- } \\
\text { contents in } \\
\text { seeds }\end{array}$ & $\begin{array}{l}\text { MS of P- } \\
\text { contents in } \\
\text { root }\end{array}$ & $\begin{array}{l}\text { MS of P- } \\
\text { contents in } \\
\text { stem }\end{array}$ & $\begin{array}{l}\text { MS of P- } \\
\text { contents in } \\
\text { leaves }\end{array}$ & $\begin{array}{c}\text { MS of P } \\
\text { contents in } \\
\text { seeds }\end{array}$ \\
\hline Location & 9 & $77.480 * * *$ & $75.969 * * *$ & $91.247 * * *$ & $53.470 * * *$ & $94.388 * * *$ & $82.112 * * *$ & $108.027 * * *$ & $94.804 * * *$ & $0.0026530 * * *$ & $0.016790 * * *$ & $0.002950 * * *$ & $0.000515^{* * *}$ \\
\hline Year & 1 & $137.124 * * *$ & $85.748 * * *$ & $427.662 * * *$ & $165.894 * * *$ & $90.250 * * *$ & $327.610^{* * * *}$ & $33.640 * * *$ & $17.640^{* * *}$ & $0.001600^{* * *}$ & $0.027275^{* * *}$ & $0.005127 * * *$ & $0.001190^{* * *}$ \\
\hline Location $\times$ year & 9 & $0.932 \mathrm{~ns}$ & $1.824 \mathrm{~ns}$ & $2.310 \mathrm{~ns}$ & $1.546 \mathrm{~ns}$ & $2.406 \mathrm{~ns}$ & $2.032 \mathrm{~ns}$ & $2.262 \mathrm{~ns}$ & $1.440 \mathrm{~ns}$ & $0.000083 \mathrm{~ns}$ & $0.000772 \mathrm{~ns}$ & $0.000012 \mathrm{~ns}$ & $0.000010 \mathrm{~ns}$ \\
\hline Error & 80 & 2.322 & 2.032 & 4.072 & 1.536 & 3.150 & 2.770 & 2.795 & 2.100 & 0.000222 & 0.000633 & 0.000025 & 0.000014 \\
\hline Total & 99 & 185.74 & 948.44 & 1595.46 & 783.95 & 1213.39 & 136.51 & 1249.84 & 1051.84 & 0.226950 & 0.048253 & 0.33789 & 0.007005 \\
\hline
\end{tabular}




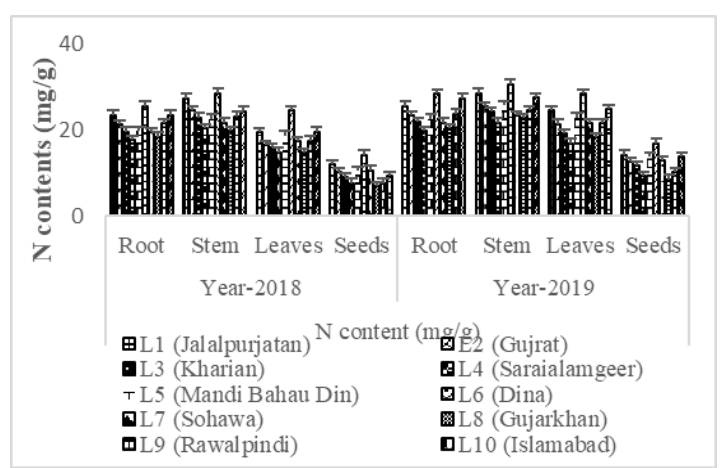

(A) Nitrogen contents $(\mathrm{mg} / \mathrm{g})$

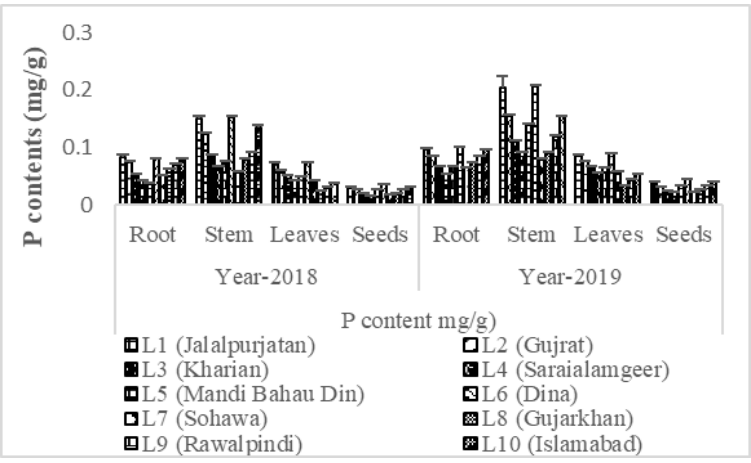

(B) potassium contents $(\mathrm{mg} / \mathrm{g})$

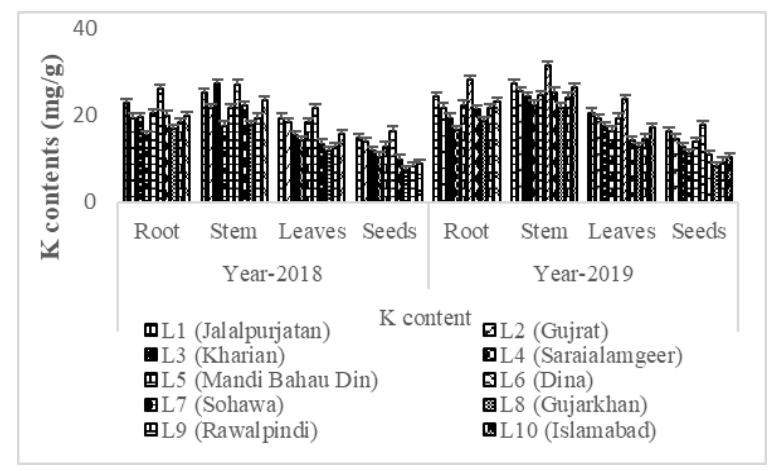

(C) Phosphorous contents (mg/g)

Figure 3. Influence of climatic conditions on ions concentrations of milk thistle (Silybum marianum) at various ecological locations

\section{Potassium (K) contents ( $\mathrm{mg} / \mathrm{g}$ )}

Maximum potassium contents were noted in stem and minimum in seeds during both the years (Fig. 3B). ANOVA results showed that Location Dina showed maximum potassium contents on various parts of the plant (Table 5). Diverse climate (temperature, rain fall and soil) had highly significant results on different locations as well as years for $\mathrm{K}$ contents. While the interaction between years and location showed non-significant results. It was observed that maximum $\mathrm{K}$ contents were measured during 2019 from all locations as compared to 2018.

\section{Phosphorous (P) contents ( $\mathrm{mg} / \mathrm{g})$}

Table 3 showed the impacts of environmental factors on phosphorous contents on root, stem, leaves and seeds. There were highly significant among different locations and years. However, its interaction was non-significant (Table 5). Figure 3C showed that maximum phosphorous contents were present in stem and seeds during 2018 and 2019. Maximum phosphorous contents were measured in Location-1 (Jalalpur Jattan) and Location-6 (Dina) during both the years (2018 and 2019).

\section{Discussion}

It is observed that changes occurring in the environment create negative effects on milk thistle. These effects create an impression on the physiology of this plant and change it in various respects. Researches carried out to notice such type of changes have 
shown reductions in chlorophyll pigment in numerous plants as Eucalyptus citriodora, Mangifera indica, Shorea robusta, Tectona grandis (Joshi and Sawami, 2007), Duranta repens (Raina and Bala, 2011), Prosopis juliiflora (Seyyednejad and Koochak, 2013) and Artemisia maritima (Laghari et al., 2015) as a result of the effects of environmental changes. It is, therefore, argued that a decrease within the pigment contents that results from the impact of various factors in the environment creates a degradation of pigments and destruction of plastid in cells (Satija et al., 2009). Swaisgood et al. (2018) also reported in earlier study that variations in the environment cause a decrease in photosynthetic pigments of plants.

The photosynthetic machinery of plants is sensitive to temperature especially biosynthesis of chlorophyll, activity of enzyme Rubisco, PS- II and net rate of photosynthesis are the main targets of heat damage in plants (Sinsawat et al., 2004). Heat stress damage the process of photosynthesis in plants which lead to photoinhibition. As a result reduced electron acceptors accumulates and reactive oxygen species form (hydrogen peroxide) hence cause oxidative damage (Cui et al., 2006). Heat stress causes the accumulation ROS in excess amount at cellular level leading to lipid peroxidation and damage nucleic acid, proteins and especially photosynthetic pigments (Wang et al., 2014). Due to climatic conditions related to temperature stress, $15-20 \%$ of maize production has been lost throughout the world (Chen et al., 2012). The C4 plants like maize are more adapted to temperature stress but net rate of photosynthesis drops down when temperature of leaves of this plant increases up to $38^{\circ} \mathrm{C}$ (Crafts-Brandner and Salvucci, 2002; Coskun, 2011).

Due to global warming, air vapor pressure deficit of leaves will increase (Kirschbaum, 2000; Way et al., 2013). So the rate of transpiration may also increase in high temperature (Rawson et al., 1977; Kirschbaum, 2004). However, plants may close their stomata to cope with high temperature so that water loss may be prevented in arid ecosystem (Larcher, 2003). After that the rate of transpiration can decrease under warming climate. Previous studies showed that under supplemental precipitation, the rate of transpiration in plants was also high (Wullschleger and Hanson, 2006; Patrick et al., 2007). According to Starck et al. (1993) stomatal conductance decrease in tomato when temperature increases. Von Caemmerer and Farquhar (1981) reported that net changes in the rate of $\mathrm{CO}_{2}$ show fluctuations in both conductance of stomata and capacity of mesophyll cells for the process of photosynthesis. According to Camejo et al. (2006), reduced $\mathrm{CO}_{2}$ assimilation was seen in heat shocked Amalia plants could be due to decreased stomatal conductance, but fluorescence emission of chlorophyll in the genotype of Amalia was also altered because of heat shock, showing to modifications in mesophyll content of leaf.

High temperature (above $33^{\circ} \mathrm{C}$ ) cause oxidative stress that degrade the proteins and enzyme activity which in turns damage the cell membrane (Bavita et al., 2012). The rate of respiration in plants increase in high temperature that enhance antioxidant response to accumulation of reactive oxygen species (ROS) in mitochondria. According to Dizengremel (2001), increased NADH synthesis enhance SOD formation under high rate of respiration. Respiration rate and SOD-manganese enzyme activity increase due to heat stress in Nicotiana plumbagifolia (Bowler et al., 1992). Alterations in evapotranspiration and ambient temperature were highly significant among environmental fluctuations. Osmotic strain over the leaves and induction enzymatic antioxidants caused by these fluctuations are well reported in abiotic stresses such as heat stress (Wahid et al., 2007), cold stress (Wu et al., 1999; McKersie et al., 1999), 
high light intensity (Gupta et al., 1993) and drought stress (Farooq et al., 2009). Various other studies have reported that different conditions of agriculture can influence concentration of bioactive compounds like silymarin in milk thistle. Hammouda et al. (1993) reported that individual silymarin constituents and silymarin levels were influenced by levels of nitrogen and moisture availability. In the plants grown at $60 \%$ field capacity, highest level of silymarin $(63.1 \%$ Silymarin in ethyl acetate extract) was observed. At this water level, the levels of silybin, silychristin and isosilybin were also highest.

\section{Conclusion and recommendations}

It was concluded that milk thistle plants were flourishing best at location Dina that had an optimum soil characteristics i.e. Sandy loam, $0.65 \mathrm{dS} / \mathrm{m}$ EC, $0.65 \%$ organic matter and $47 \%$ soil saturation) and climatic conditions (a maximum temperature of $25^{\circ} \mathrm{C}$, average temperature of $21^{\circ} \mathrm{C}$ and high amounts of rainfall $(838 \mathrm{~mm})$ with $84 \%$ humidity). So, it is proposed that such categories of soil and climatic conditions are best for the cultivation of milk thistle at commercial scale. These physiological and biochemical indicators can be used to evaluate the milk thistle response towards diverse climatic conditions.

It is recommended to grow the milk thistle at an average temperature of $25^{\circ} \mathrm{C}$, rainfall amount $838 \mathrm{~mm}$ and humidity $84 \%$. Further studies are required to evaluate its active constituents at varied climatic conditions for quality medicines.

\section{REFERENCES}

[1] Abenavoli, L., Izzo, A. A., Milic, N., Cicala, C., Santini, A., Capasso, R. (2018): Milk thistle (Silybum marianum): a concise overview on its chemistry, pharmacological, and nutraceutical uses in liver diseases. - Phytotherapy Research 32: 2202-2213.

[2] Ahmad, I., Hussain, M., Ahmad, M. S. A., Ashraf, M. Y., Ahmad, R., Ali, A. (2008): Spatio-temporal variations in physiochemical attributes of Adiantum capillus-veneris from Soone Valley of salt range (Pakistan). - Pakistan Journal of Botany 40: 13871398.

[3] Ahmad, I., Ahmad, M. S. A., Hussain, M., Hameed, M., Ashraf, M. Y., Koukab, M. Y. (2009): Spatio-temporal effects on species classification of medicinal plants in Soone Valley of Pakistan. - International Journal of Agriculture and Biology 11: 64-68.

[4] Alemardan, A., Karkanis, A., Salehi, R. (2013): Breeding objectives and selection criteria for milk thistle (Silybum marianum (L.) Gaertn.) improvement. - Notulae Botanicae Horti Agrobotanici Cluj-Napoca 41: 340-347.

[5] Andrzejewska, J., Sadowska, K. (2008): Effect of cultivation conditions on the variability and interrelation of yield and raw material quality in milk thistle (Silybum marianum (L.) Gaertn.). - Acta Scientiarum Polonorum Agricultura 7(3): 3-7.

[6] Arnon, D. I. (1949): Copper enzymes in isolated chloroplasts. Polyphenoloxidase in Beta vulgaris. - Plant Physiology 24: 1.

[7] Bailly, M., Condeelis, J. S., Segall, J. E. (1998): Chemoattractant-induced lamellipod extension. - Microscopy Research and Technique 43: 433-443.

[8] Bavita, A., Shashi, B., Navtej, S. B. (2012): Nitric oxide alleviates oxidative damage induced by high temperature stress in wheat. - Indian Journal of Experimental Biology 50(5): 372-380.

[9] Bacon, M. (Ed.) (2009): Water Use Efficiency in Plant Biology. - John Wiley \& Sons, New York. 
[10] Bijak, M. (2017): Silybin, a major bioactive component of milk thistle (Silybum marianum L. Gaernt.). - Chemistry, Bioavailability \& Metabolism Molecules 22: 1942.

[11] Bowler, C., Montagu, M. V.., Inze, D. (1992): Superoxide dismutase and stress tolerance. - Annual Review of Plant Biology 43: 83-116.

[12] Bremner, J. M. (1965): Total Nitrogen. - In: Black, C. A. (ed.) Methods of Soil Analysis. Part 2: Chemical and Microbial Properties. Number 9 in Series Agronomy. American Society of Agronomy, Inc. Publisher, Madison, WI, pp. 1049-1178.

[13] Camejo, D., Ana, J., Juan, J. A., Walfredo, T., Juana, M. G., Francisca, S. (2006): Changes in photosynthetic parameters and antioxidant activities following heat-shock treatment in tomato plants. - Functional Plant Biology 33: 177-187.

[14] Carlsson, G. E., Moller, A., Blomstrand, C., Ueda, T., Mizushige, K., Yukiiri, K., Yang, C. C. (2003): European stroke initiative recommendations for stroke management - update 2003. - Cerebrovascular Diseases 16: 311-337.

[15] Chance, M., Maehly, A. C. (1955): Assay of catalases and peroxidases. - Methods in Enzymology 2: 764-817.

[16] Chen, W. E. N. R. O. N. G., Cen, W., Chen, L., Di, L., Li, Y.-Q., Guo, W. (2012): Differential sensitivity of four highbush blueberry (Vaccinium corymbosum L.) cultivars to heat stress. - Pakistan Journal of Botany 44: 853-860.

[17] Coskun, Y., Coskun, A., Demirel, U., Ozden, M. (2011): Physiological response of maize ('Zea mays L.) to high temperature stress. - Australian Journal of Crop Science 5: 966.

[18] Crafts-Brandner, S. J., Salvucci, M. E. (2002): Sensitivity of photosynthesis in a C4 plant, maize, to heat stress. - Plant Physiology 129: 1773-1780.

[19] Cui, L., Li, J., Fan, Y., Xu, S., Zhang, Z. (2006): High temperature effects on photosynthesis, PSII functionality and antioxidant activity of two Festuca arundinacea cultivars with different heat susceptibility. - Botanical Studies 47: 61-69.

[20] Cui, L. L., Kerkela, E., Bakreen, A., Nitzsche, F., Andrzejewska, A., Nowakowski, A., Jolkkonen, J. (2015): The cerebral embolism evoked by intra-arterial delivery of allogeneic bone marrow mesenchymal stem cells in rats is related to cell dose and infusion velocity. - Stem Cell Research and Therapy 6: 11.

[21] Dizengremel, P. (2001): Effects of ozone on the carbon metabolism of forest trees. Plant Physiology \& Biochemistry 39: 729-742.

[22] Dominguez, M. T., Montiel-Rozas, M. M., Madejon, P., Diaz, M. J., Madejon, E. (2017: The potential of native species as bioenergy crops on trace-element contaminated Mediterranean lands. - Science of the Total Environment 590: 29-39.

[23] Farooq, M., Wahid, A., Kobayashi, N., Fujita, D. B. S. M. A., Basra, S. M. A. (2009): Plant Drought Stress: Effects, Mechanisms and Management. - In: Lichtfouse, E. et al. (eds.) Sustainable Agriculture. Springer, Dordrecht, pp. 153-188.

[24] Gairola, S., Shariff, N. M., Bhatt, A. (2010): Influence of climate change on production of secondary chemicals in high altitude medicinal plants: issues needs immediate attention. - Journal of Medicinal Plants Research 4: 1825-1829.

[25] Ghimire, S. K., Mckey, D., Aumeeruddy-Thomas, Y. (2006): Himalayan medicinal plant diversity in an ecologically complex high altitude anthropogenic landscape, Dolpo, Nepal. - Environmental Conservation 33: 128-140.

[26] Giannopolitis, C. N., Ries, S. K. (1977): Superoxide dismutases: I. Occurrence in higher plants. - Plant Physiology 59: 309-314.

[27] Guo, S. W., Zhou, Yi., Song, N., Shen, Q. (2006): Some physiological processes related to water use efficiency of higher plants. - Agricultural Sciences in China 5: 403-411.

[28] Gupta, A. S., Heinen, J. L., Holaday, A. S., Burke, J. J., Allen, R. D. (1993): Increased resistance to oxidative stress in transgenic plants that overexpress chloroplastic $\mathrm{Cu} / \mathrm{Zn}$ 
superoxide dismutase. - Proceedings of the National Academy of Sciences 90: 16291633.

[29] Hammouda, F. M., Ismail, S. I., Hassan, N. M., Zaki, A. K., Kamel, A., Rimpler, H. (1993): Evaluation of the silymarin content in Silybum marianum (L.) Gaertn. Cultivated under different agricultural conditions. - Phytotherapy Research 7: 90-91.

[30] Herath, H. M. W., Ormrod, D. P. (1979): Effects of temperature and photoperiod on winged beans (Psophocarpus tetragonolobus L. DC). - Annals of Botany 43: 729-736.

[31] Jackson, M. L. (1962): Soil Chemical Analysis. - Constable and Co. Ltd., London.

[32] Joshi, P. C., Swami, A. (2007): Physiological responses of some tree species under roadside automobile pollution stress around city of Haridwar, India. - The Environmentalist 27: 365-374.

[33] Karkanis, A., Bilalis, D., Efthimiadou, A. (2011): Cultivation of milk thistle (Silybum marianum L. Gaertn.), a medicinal weed. - Industrial Crops and Products 34: 825-830.

[34] Keleş, Y., Oncel, I. (2002): Response of antioxidative defence system to temperature and water stress combinations in wheat seedlings. - Plant Science 163: 783-790.

[35] Khalid, N., Mumtaz, H., Mansoor, H., Rashid, A. (2017): Physiological, biochemical and defense system response of parthenium hysterophorus to vehicular exhaust pollution. - Pakistan Journal of Botany 49: 67-75.

[36] Kirschbaum, M. U. (2000): Forest growth and species distribution in a changing climate. - Tree Physiology 20: 309-322.

[37] Kirschbaum, M. U. F. (2004): Direct and indirect climate change effects on photosynthesis and transpiration. - Plant Biology 6: 242-253.

[38] Kumar, A., Kaul, M. K., Bhan, M. K., Khanna, P. K., Suri, K. A. (2007): Morphological and chemical variation in 25 collections of the Indian medicinal plant, Withania somnifera (L.) Dunal (Solanaceae). - Genetic Resources \& Crop Evolution 54: 655-660.

[39] Laghari, M., Mirjat, M. S., Hu, Z., Fazal, S., Xiao, B., Hu, M., Guo, D. (2015): Effects of biochar application rate on sandy desert soil properties and sorghum growth. Catena 135: 313-320.

[40] Larcher, W. (2003): Ecophysiology and Stress Physiology of Functional Groups. - In: Larcher, W. (ed.) Physiological Plant Ecology. Springer Science \& Business Media, Berlin.

[41] Litvak, M. E., Constable, J. V., Monson, R. K. (2002): Supply and demand processes as controls over needle monoterpene synthesis and concentration in Douglas fir (Pseudotsuga menziesii (Mirb.). - Oecologia 132: 382-391.

[42] Lohrmann, N. L., Logan, B. A., Johnson, A. S. (2004): Seasonal acclimatization of antioxidants and photosynthesis in Chondrus crispus and Mastocarpus stellatus, two co-occurring red algae with differing stress tolerances. - The Biological Bulletin 207: 225-232.

[43] McKersie, B. D., Bowley, S. R., Jones, K. S. (1999): Winter survival of transgenic alfalfa overexpressing superoxide dismutase. - Plant Physiology 119: 839-848.

[44] Patrick, L., Cable, J., Potts, D., Ignace, D., Barron-Gafford, G., Griffith, A., Zak, J. (2007): Effects of an increase in summer precipitation on leaf, soil, and ecosystem fluxes of $\mathrm{CO}_{2}$ and $\mathrm{H}_{2} \mathrm{O}$ in a sotol grassland in Big Bend National Park, Texas. Oecologia 151: 704-718.

[45] Raina, A. K., Bala, C. (2011): Effect of vehicular pollution on Duranta repens L. in Jammu City. - Journal of Applied and Natural 3: 211-218.

[46] Rawson, H. M., Begg, J. E., Woodward, R. G. (1977): The effect of atmospheric humidity on photosynthesis, transpiration and water use efficiency of leaves of several plant species. - Planta 134: 5-10.

[47] Root, T. L., Price, J. T., Hall, K. R., Schneider, S. H., Rosenzweig, C., Pounds, J. A. (2003): Fingerprints of global warming on wild animals and plants. - Nature 421: 57. 
[48] Satija, N. K., Singh, V. K., Verma, Y. K., Gupta, P., Sharma, S., Afrin, F. (2009): Mesenchymal stem cell-based therapy: a new paradigm in regenerative medicine. Journal of Cellular and Molecular Medicine 13: 4385-4402.

[49] Sen, S., Mukherji, S. (2000): Season-induced alterations in levels of antioxidants and polygalacturonase activity in tomato (Lycopersicon esculentum Mill.) fruit. - Journal of Environment and Pollution 7: 303-308.

[50] Sersen, F., Vencel, T., Annus, J. (2006): Silymarin and its components scavenge phenylglyoxylic ketyl radicals. - Fitoterapia 77: 525-529.

[51] Seyyedneiad, S. M., Koochak, H. (2013): Some morphological and biochemical responses due to industrial air pollution in Prosopis juliflora (Swartz) DC plant. African Journal of Agricultural Research 8: 1968-1974.

[52] Silverman, B. W. (2018): Density Estimation for Statistics and Data Analysis. - CRC Press, Taylor \& Francis Group, Routledge.

[53] Sinsawat, V., Leipner, J., Stamp, P., Fracheboud, Y. (2004): Effect of heat stress on the photosynthetic apparatus in maize (Zea mays L.) grown at control or high temperature. - Environmental and Experimental Botany 52: 123-129.

[54] Snow, M. D., Bard, R. R., Olszyk, D. M., Minster, L. M., Hager, A. N., Tingey, D. T. (2003): Monoterpene levels in needles of Douglas fir exposed to elevated $\mathrm{CO}_{2}$ and temperature. - Physiologia Plantarum 117: 352-358.

[55] Starck, Z., Wazynska, Z., Kucewicz, O. (1993): Comparative effects of heat stress on photosynthesis and chloroplast ultrastructure in tomato plants with source-sink modulated by growth regulators. - Acta Physiologiae Plantarum 15: 125-133.

[56] Swaisgood, R. R., Wang, D., Wei, F. (2018): Panda downlisted but not out of the woods. - Conservation Letters 11: 12355.

[57] Tholl, D., Boland, W., Hansel, A., Loreto, F., Rose, U. S., Schnitzler, J. P. (2006): Practical approaches to plant volatile analysis. - The Plant Journal 45: 540-560.

[58] Von Caemmerer, S. V., Farquhar, G. D. (1981): Some relationships between the biochemistry of photosynthesis and the gas exchange of leaves. - Planta 153: 376-387.

[59] Wahid, A., Gelani, S., Ashraf, M., Foolad, M. R. (2007): Heat tolerance in plants: an overview. - Environmental \& Experimental Botany 61: 199-223.

[60] Wang, C., Wen, D., Sun, A., Han, X., Zhang, J., Wang, Z., Yin, Y. (2014): Differential activity and expression of antioxidant enzymes and alteration in osmolyte accumulation under high temperature stress in wheat seedlings. - Journal of Cereal Science 60: 653-659.

[61] Way, D. A., Domec, J. C., Jackson, R. B. (2013): Elevated growth temperatures alter hydraulic characteristics in trembling aspen (Populus tremuloides) seedlings: implications for tree drought tolerance. - Plant, Cell \& Environment 36: 103-115.

[62] Wolf, B. (1982): A comprehensive system of leaf analyses and its use for diagnosing crop nutrient status. - Communications in Soil Science and Plant Analysis 13: 10351059.

[63] Wong, E. H., Kemp, J. A., Priestley, T., Knight, A. R., Woodruff, G. N., Iversen, L. L. (1986): The anticonvulsant MK-801 is a potent N-methyl-D-aspartate antagonist. Proceedings of the National Academy of Sciences 83: 7104-7108.

[64] Wu, G., Wilen, R. W., Robertson, A. J., Gusta, L. V. (1999): Isolation, chromosomal localization, and differential expression of mitochondrial manganese superoxide dismutase and chloroplastic copper/zinc superoxide dismutase genes in wheat. - Plant Physiology 120: 513-520.

[65] Wullschleger, S. D., Hanson, P. J. (2006): Sensitivity of canopy transpiration to altered precipitation in an upland oak forest: evidence from a long-term field manipulation study. - Global Change Biology 12: 97-109. 


$$
\text { - } 4623 \text { - }
$$

\section{APPENDIX}

Figure A1. Map showing the different locations where study was conducted

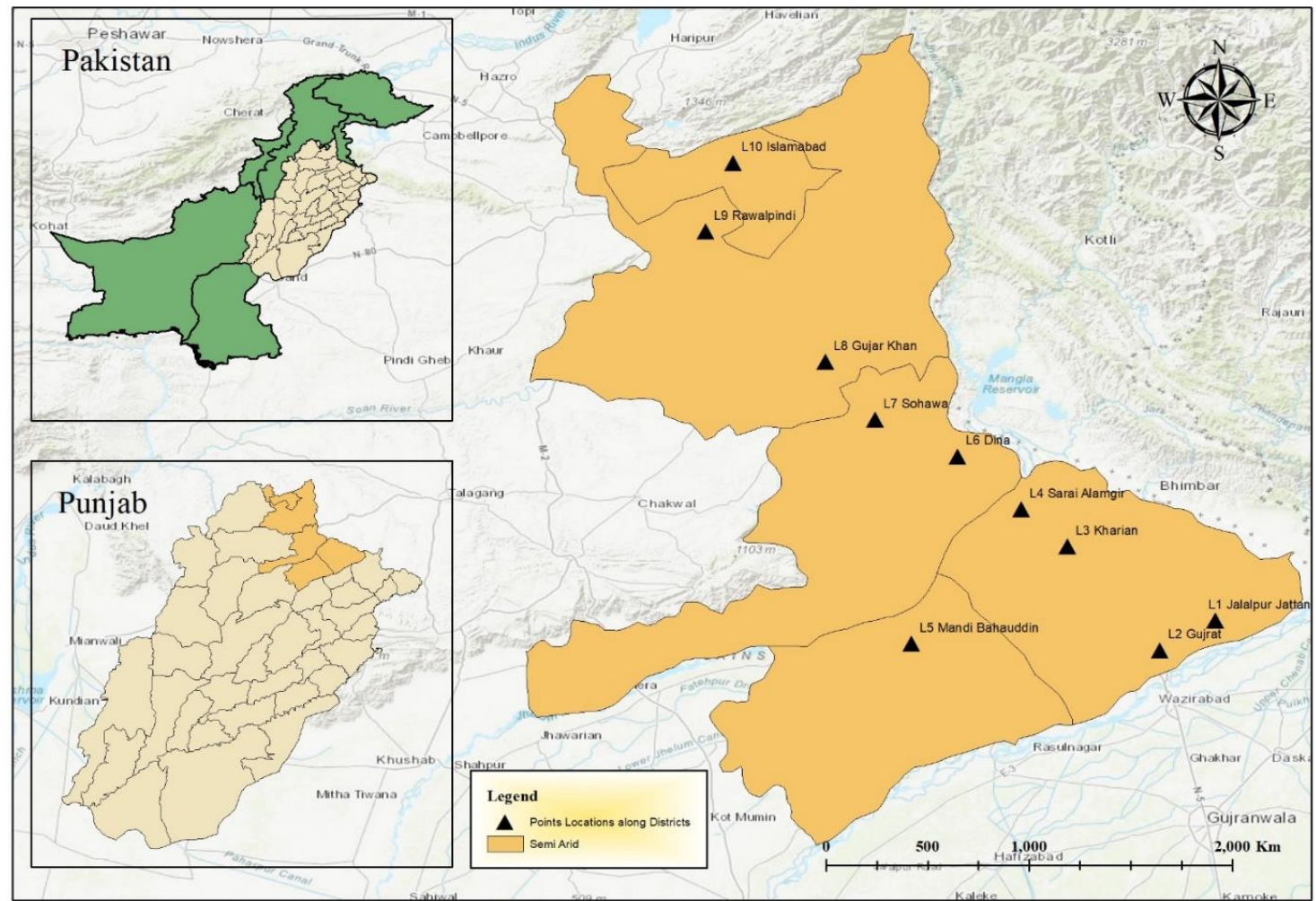

